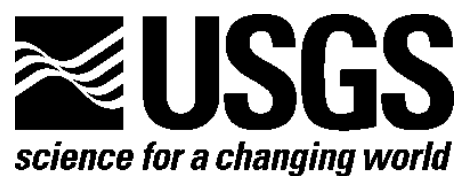

P2S-Coupled Simulation with the Precipitation-Runoff Modeling System (PRMS) and the Stream Temperature Network (SNTemp) Models

By Steven L. Markstrom

Open-File Report 2012-1116

U.S. Department of the Interior

U.S. Geological Survey 


\section{U.S. Department of the Interior \\ KEN SALAZAR, Secretary}

\section{U.S. Geological Survey \\ Marcia K. McNutt, Director}

U.S. Geological Survey, Reston, Virginia: 2012

For more information on the USGS-the Federal source for science about the Earth,

its natural and living resources, natural hazards, and the environment-visit

http://www.usgs.gov or call 1-888-ASK-USGS

For an overview of USGS information products, including maps, imagery, and publications, visit $h$ ttp://www.usgs.gov/pubprod

To order this and other USGS information products, visit http://store.usgs.gov

Suggested citation:

Markstrom, S.L., 2012, P2S—Coupled simulation with the Precipitation-Runoff Modeling System (PRMS) and the Stream Temperature Network (SNTemp) Models: U.S. Geological Survey Open-File Report 2012-1116, 19 p.

Any use of trade, product, or firm names is for descriptive purposes only and does not imply endorsement by the U.S. Government.

Although this report is in the public domain, permission must be secured from the individual copyright owners to reproduce any copyrighted material contained within this report. 


\section{Contents}

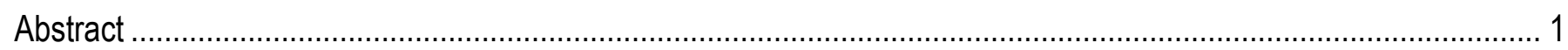

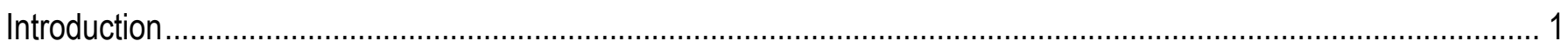

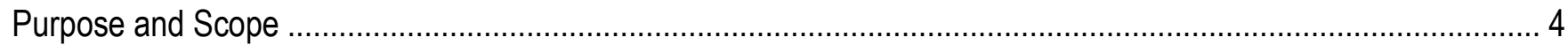

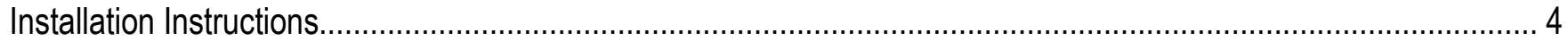

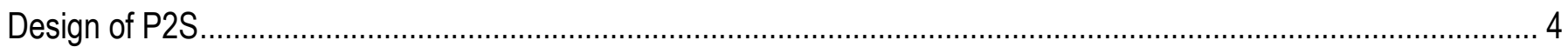

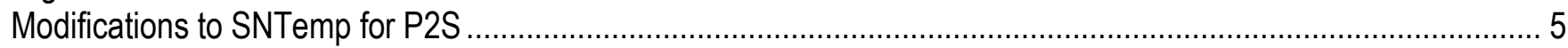

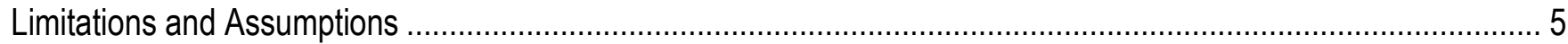

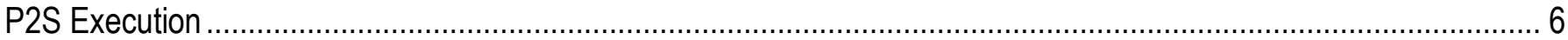

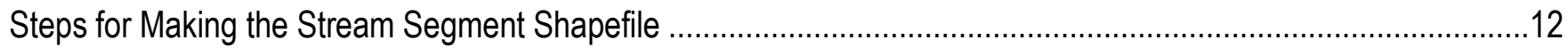

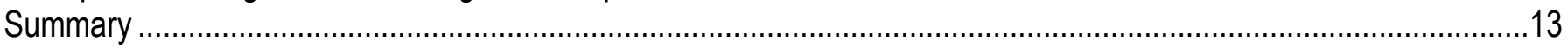

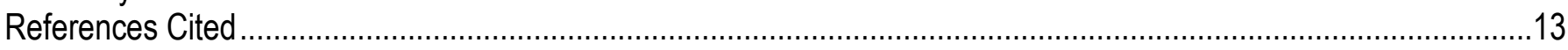

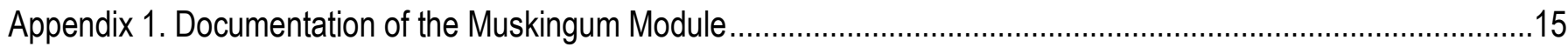

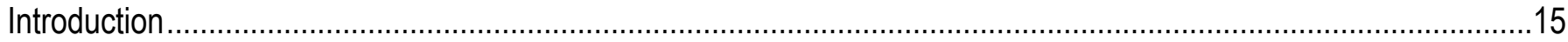

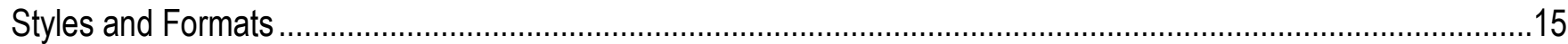

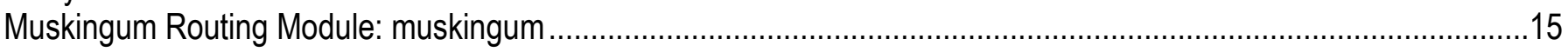

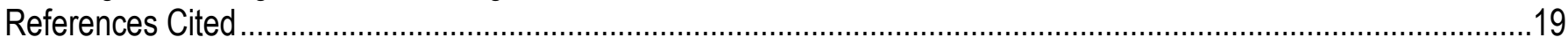

\section{Figures}

Figure 1. Diagram showing the hydrologic components as conceptualized in the Precipitation Runoff Modeling System (modified from Leavesley and others, 1983).

Figure 2. Diagram showing the energy and water components in a stream segment as conceptualized in the Stream Network Temperature Model (from Bartholow, 2000).

Figure 3. Diagram showing the information flow between the Precipitation Runoff Modeling System (PRMS), P2S, and the Stream Network Temperature Model (SNTemp). The sequence of execution starts on the left with the inputs to PRMS, progresses towards the right, through P2S, and finishes with the output files produced by SNTemp .......... 5

Figure 4. A screen image of an ESRI ArcMap project showing a stream segment network shapefile and the associated attribute table. 8

Figure 5. A portion of the Extensible Markup Language (.xml) format file containing Stream Network Temperature Model input values. 10 


\section{Tables}

Table 1. Precipitation Runoff Modeling System (PRMS) variables which must be written to the PRMS animation file to be used as input by P2S.

Table 2. Attributes which must be present in the Stream Segement shapefile coverage to describe the topology and physical attributes of the stream segement network to P2S.

Table 3. Stream Network Temperature Model (SNTemp) input values which must be present in "p2s.xml" input

file. These values are described by Theurer and others (1984, p. III-63-III-92)

Table A1-1.-Input parameters to Streamflow Module: muskingum 16

Table A1-2. - Variables used in Streamflow Module: muskingum 


\section{Conversion Factors}

Inch/Pound to SI

\begin{tabular}{lcl}
\hline Multiply & By & To obtain \\
\hline & Length & \\
\hline inch (in.) & 2.54 & centimeter (cm) \\
inch (in.) & 25.4 & millimeter (mm)
\end{tabular}

\begin{tabular}{lcl}
\hline & Flow rate & \\
\hline cubic foot per second $\left(\mathrm{ft}^{3} / \mathrm{s}\right)$ & 0.02832 & $\begin{array}{l}\text { cubic meter per second } \\
\left(\mathrm{m}^{3} / \mathrm{s}\right)\end{array}$
\end{tabular}

SI to Inch/Pound

\begin{tabular}{lll}
\hline \multicolumn{1}{c}{ Multiply } & By & \multicolumn{1}{c}{ To obtain } \\
\hline centimeter $(\mathrm{cm})$ & 0.3937 & inch (in.) \\
millimeter $(\mathrm{mm})$ & 0.03937 & inch (in.) \\
meter $(\mathrm{m})$ & 3.281 & foot $(\mathrm{ft})$ \\
\hline & Area & \\
\hline square meter $\left(\mathrm{m}^{2}\right)$ & 0.0002471 & acre \\
\hline & Volume & \\
\hline cubic meter $\left(\mathrm{m}^{3}\right)$ & 35.31 & cubic foot $\left(\mathrm{ft}^{3}\right)$ \\
\hline & Flow rate & \\
\hline meter per second $(\mathrm{m} / \mathrm{s})$ & 3.281 & foot per second $(\mathrm{ft} / \mathrm{s})$ \\
cubic meter per second $\left(\mathrm{m}^{3} / \mathrm{s}\right)$ & 35.31 & cubic foot per second $\left(\mathrm{ft}^{3} / \mathrm{s}\right)$ \\
\hline & Mass & \\
\hline gram $(\mathrm{g})$ & 0.03527 & ounce, avoirdupois $(\mathrm{oz})$ \\
\hline & Energy & \\
\hline joule $(\mathrm{J})$ & 0.0000002 & kilowatthour $(\mathrm{kWh})$ \\
\hline
\end{tabular}

Temperature in degrees Celsius $\left({ }^{\circ} \mathrm{C}\right)$ may be converted to degrees Fahrenheit $\left({ }^{\circ} \mathrm{F}\right)$ as follows:

${ }^{\circ} \mathrm{F}=\left(1.8 \mathrm{x}^{\circ} \mathrm{C}\right)+32$

The solar radiation unit, Langley, is 1 gram-calorie per square centimeter or 11.622 watt-hours per square meter. 


\title{
P2S-Coupled Simulation with the Precipitation-Runoff Modeling System (PRMS) and the Stream Temperature Network (SNTemp) Models
}

\author{
By Steven L. Markstrom
}

\begin{abstract}
A software program, called P2S, has been developed which couples the daily stream temperature simulation capabilities of the U.S. Geological Survey Stream Network Temperature model with the watershed hydrology simulation capabilities of the U.S. Geological Survey Precipitation-Runoff Modeling System. The Precipitation-Runoff Modeling System is a modular, deterministic, distributedparameter, physical-process watershed model that simulates hydrologic response to various combinations of climate and land use. Stream Network Temperature was developed to help aquatic biologists and engineers predict the effects of changes that hydrology and energy have on water temperatures. P2S will allow scientists and watershed managers to evaluate the effects of historical climate and projected climate change, landscape evolution, and resource management scenarios on watershed hydrology and in-stream water temperature.
\end{abstract}

\section{Introduction}

The importance of effective stream temperature modeling, related to determination of suitability and management of ecological habitat, has been demonstrated in several studies (for example, Brown, 1969; Flint and Flint, 2008; and Gaffield and others, 2005; Perry and others, 2011; Sinokrot and Stefan, 1993). Likewise, watershed hydrology models have been used to project the hydrologic response of watersheds to a variety of changing climatic and land-use scenarios (for example, Hay and others, 2011; Markstrom and others, 2012). P2S combines these two approaches by coupling the Precipitation-Runoff Modeling System (PRMS) and Stream Network Temperature (SNTemp) simulations models. These two models are described below.

Markstrom and others (2008, p. 4) describe PRMS as a modular, deterministic, distributedparameter, physical-process watershed model used to simulate and evaluate the effects of various combinations of precipitation, climate, and land use on watershed response. Response to normal and extreme rainfall and snowmelt can be simulated to evaluate changes in water-balance relations, streamflow regimes, soil-water relations, and groundwater recharge. Each hydrologic component used to model the generation of streamflow is represented within PRMS by a process algorithm that is based on a physical law or empirical relation with measured or estimated characteristics (fig. 1). Because PRMS is usually operated in a daily time step, the streamflow time of travel within a watershed should be less than 24 hours. However, for larger watersheds that have longer travel times a stream routing component can be used. The reader is referred to Leavesley and others (1983), Leavesley and Stannard (1995), Leavesley and others (2005), and Markstrom and others (2008) for a complete description of 
PRMS. These reports are available at:

http://wwwbrr.cr.usgs.gov/projects/SW_MoWS/software/oui_and_mms_s/prms.shtml, accessed March 2012.

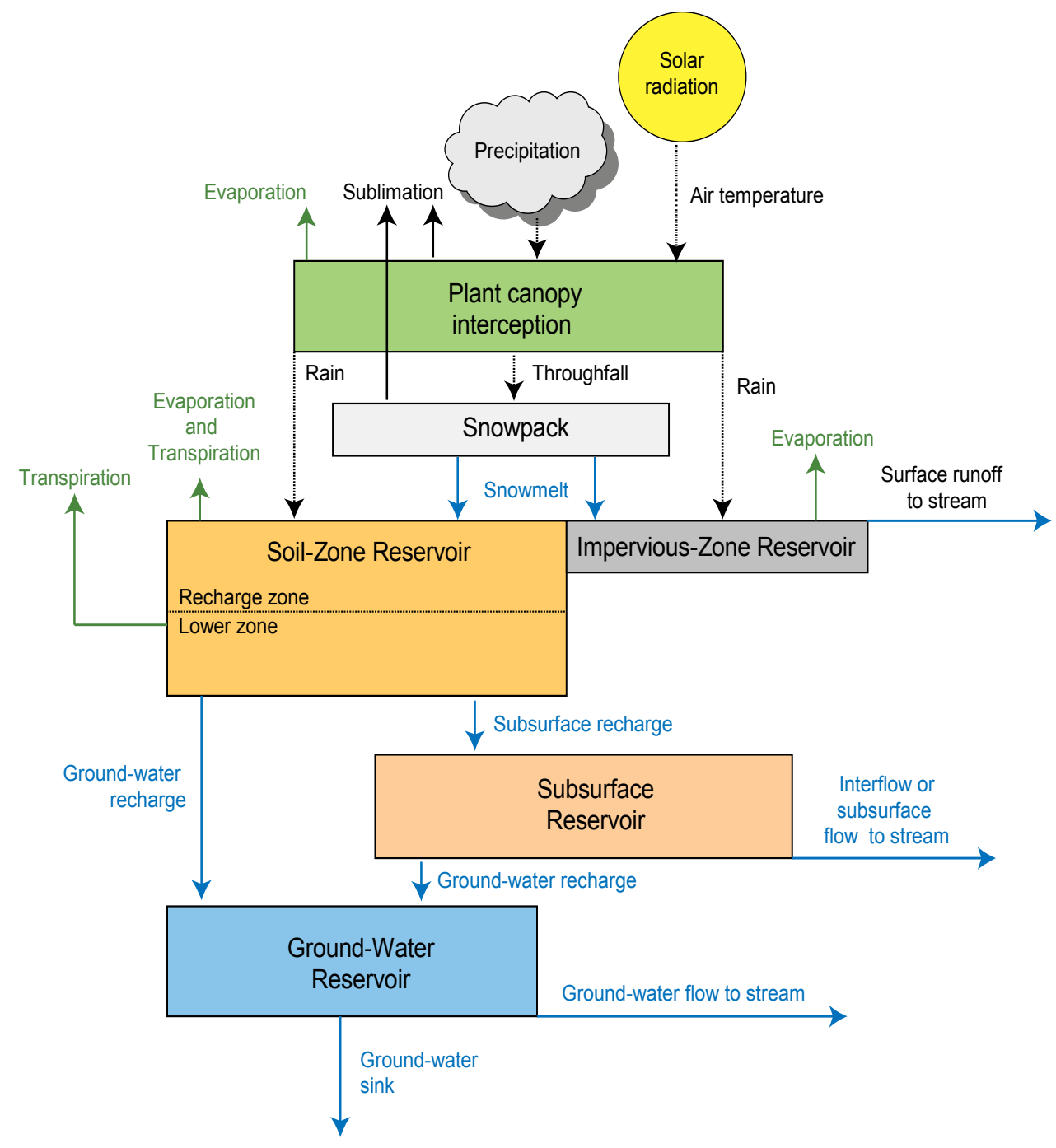

Figure 1. Diagram showing the hydrologic components as conceptualized in the Precipitation Runoff Modeling System (modified from Leavesley and others, 1983).

Theurer and others (1984, p. I-4) describe SNTemp as a model to predict in-stream water temperatures based on hydrological, meteorological, topographic and vegetative shading, and stream channel conditions (fig. 2). They describe SNTemp as being "applicable to any size watershed or river basin with a stream network of any stream order and complexity;" however, shortcomings have been found when applying SNTemp to networks where the travel time is much larger than the simulation time step. These limitations with SNTemp have been overcome by improving the streamflow routing 
algorithms of PRMS (see Appendix, this report). Despite this, SNTemp incorporates several features relevant to P2S, including: (1) a heat transport model that predicts the daily-mean water temperature and diurnal fluctuations in water temperature as functions of stream distance; (2) a heat-flux model that predicts the energy balance between the water and its surrounding environment; and (3) a shade model that predicts the solar radiation-weighted shading resulting from both topography and riparian vegetation. The reader is referred to Theurer and others (1984) and Bartholow (2000) for a complete description of SNTemp. These publications are available at:

http://www.fort.usgs.gov/products/software/SNTEMP/, accessed March 2012.

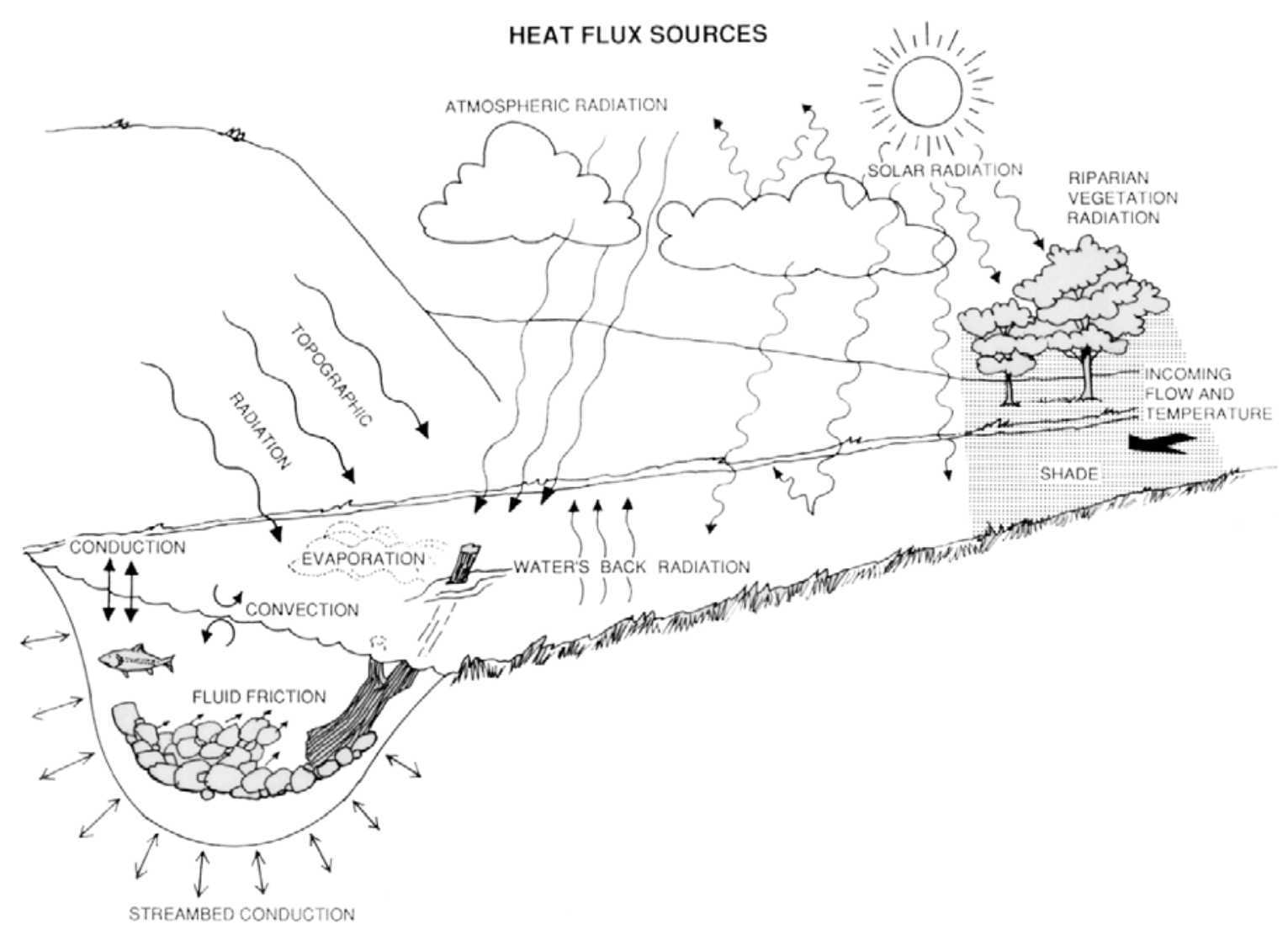

Figure 2. Diagram showing the energy and water components in a stream segment as conceptualized in the Stream Network Temperature Model (from Bartholow, 2000). 


\section{Purpose and Scope}

This report describes $\mathrm{P} 2 \mathrm{~S}$ version 1.0 and serves as the user's manual. This report describes where to get $\mathrm{P} 2 \mathrm{~S}$ and how to install it. The design concepts of $\mathrm{P} 2 \mathrm{~S}$ are presented. The steps required to execute P2S in the correct order are presented. This report is not intended as instruction for application development of PRMS or SNTemp, as these models are already documented.

\section{Installation Instructions}

The latest version of $\mathrm{P} 2 \mathrm{~S}$ is available from the $\mathrm{P} 2 \mathrm{~S}$ Web page (http://water.usgs.gov/lookup/get? crresearch/p2s, accessed April 2012) and is distributed as a zip file. About 100 megabytes of disk space are required for installation, but large applications will require much more disk space for data. This installation includes libraries, source code, startup scripts, and example datasets. Unzipping the distribution file is all that is required for installation of P2S.

In addition, P2S requires working installations of the current version of the PRMS software (http://water.usgs.gov/lookup/get? crresearch/prms, accessed March 2012) and either the SNTemp software (http://www.fort.usgs.gov/products/software/SNTEMP, accessed March 2012), as originally distributed, or a modified version, as described in the "Modifications to SNTemp for P2S" section in this report.

\section{Design of P2S}

P2S is implemented as loosely coupled software (fig. 3). There are three basic steps: (1) the user executes PRMS first, simulating daily streamflow, components of flow, solar radiation, and air temperature at each stream segment in the stream network; then, (2) the user executes P2S, which reads the output files produced by PRMS (in step 1) and creates the SNTemp input files; and finally, (3) the user executes SNTemp, with the files created in step 2, which simulates the mean daily and maximum daily temperature for each stream segment in the stream network. More details about these steps are provided below in the "P2S Execution" section of this report. 


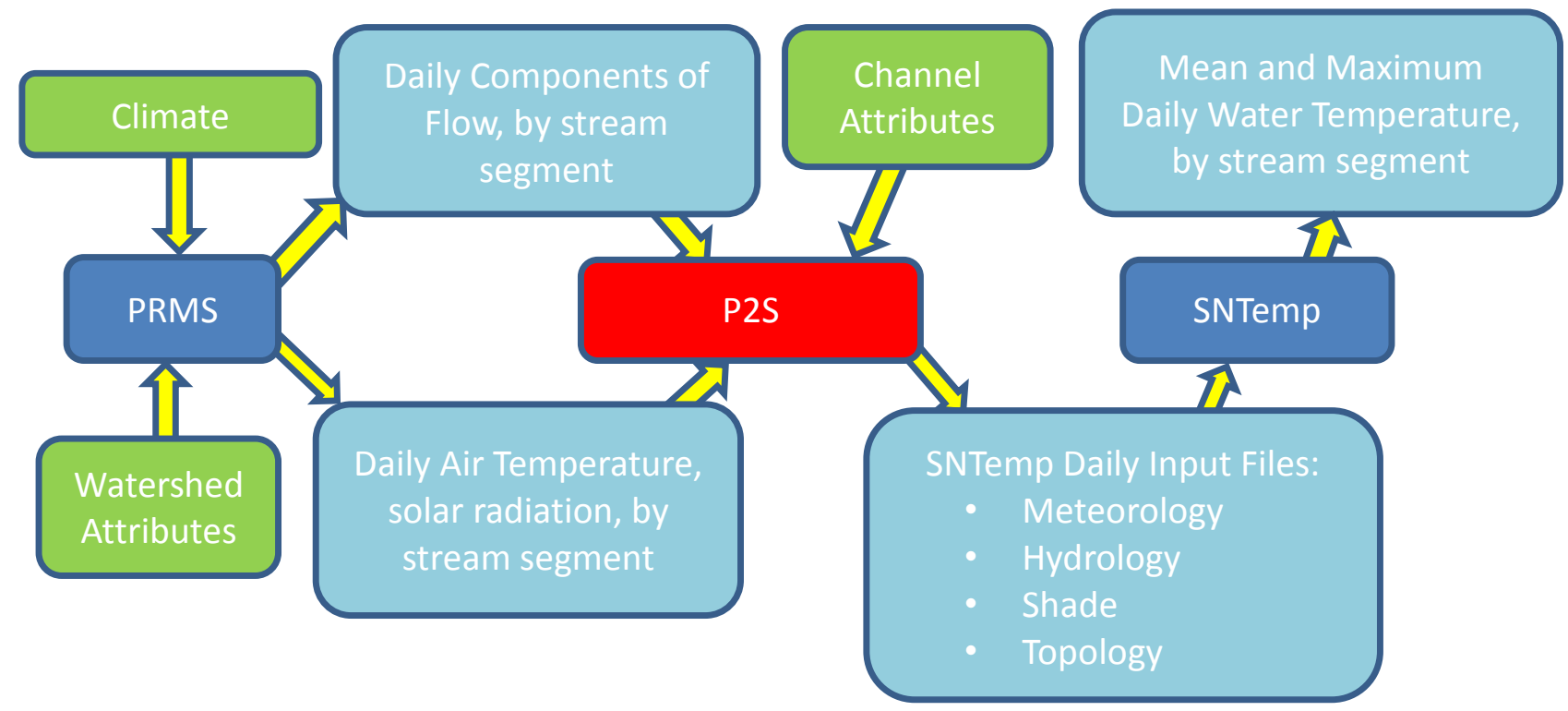

Figure 3. Diagram showing the information flow between the Precipitation Runoff Modeling System (PRMS), P2S, and the Stream Network Temperature Model (SNTemp). The sequence of execution starts on the left with the inputs to PRMS, progresses towards the right, through P2S, and finishes with the output files produced by SNTemp.

\section{Modifications to SNTemp for P2S}

The version of SNTemp distributed with $\mathrm{P} 2 \mathrm{~S}$ is identical to the version available from the SNTemp Web site (http://www.fort.usgs.gov/products/software/SNTEMP, accessed March 2012) except for two modifications to the Fortran source code. The first modification is that some of the array sizes have been increased to accommodate larger stream networks. The second modification allows for mean daily and maximum daily in-stream temperature to be printed for every stream segment, for every simulated time step, to an output file, in standard PRMS format. Thus, the same analysis and visualization tools can be used on PRMS and SNTemp output files.

\section{Limitations and Assumptions}

Anytime existing simulation models are coupled, as they are with P2S, the resulting synthesis will exhibit all of the limitations and assumptions of the original simulation models. However, in the case of P2S there may be more issues related to differences in how the two models (PRMS and SNTemp) are using common information differently. For example, although SNTemp makes adiabatic adjustments to the climate input data based on the elevation difference between the climate station and each segment, it still uses only a single climate station for the entire river configuration. PRMS, on the other hand can use numerous climate stations, and it also makes adiabatic adjustments that can be different from the way SNTemp makes adiabatic adjustments. [Pages II-29 and II-30 in Theurer and others (1984) contains information about the SNTemp adiabatic adjustments]. 


\section{P2S Execution}

These are the required steps to run PRMS and SNTemp in a coupled fashion, using P2S:

1. Install the PRMS, SNTemp, and P2S software packages.

2. Develop and calibrate the PRMS model application for the study watershed. This application requires the Muskingum module and all of the additional input defined by tables 1 through 3 .

3. Make the PRMS simulation which corresponds to the historical, current condition, climate, or land-use projection of interest. Make sure that the required output variables, basin_temp (basin area-weighted air temperature) and basin potet (basin area-weighted average of potential shortwave solar radiation), are written to the PRMS Statvar File and the PRMS Animation File (table 1), respectively. Set the PRMS Control File (described by Markstrom and others, 2008, p. 134-137) using the MMS Tool graphical editor (Markstrom and Koczot, 2008, p. 19-21).

4. SNTemp requires that all years included in the simulation have the same number of days, so remove the leap day data from the files written in step 3. Do this with a text editor or use the provided convenience script ("removeLeapDay.bat"). The Streams Editor (sed) is a convenient utility for doing this. Sed is freely available from the Gnu Organization web site (http://www.gnu.org/software/sed, accessed March 2012).

5. Open the stream segment map that was created for the PRMS model with ArcMap (fig. 4). Add the required attributes for SNTemp (table 2). This includes information about stream segment topology, geometry, and vegetation. The specific steps required to add the information to the map is described below in the "Making the Stream Segment Map" section of this report.

6. Save the stream segment map (from step 5) in Shape File Format.

7. A dBase format (.dbf) file was created in step 6. Open this file with the Excel spreadsheet program. Save this content back out in Comma Separated Value (.csv) format.

8. Edit the Extensible Markup Language format (.xml) file "p2s.xml" with a text editor so that the paths and file names are correct for the files that were just created in steps 1-7 above (fig. 5). There are also many SNTemp input parameter values in this file. These values are described by Theurer and others (1984, p. III-63-III-92) and are summarized in table 3. Edit the values in this file so that they will be changed when they are written to the SNTemp input file.

9. Execute the script "p2s.sh." This script prepares the input and job control file in the SNTemp directory to prepare the SNTemp model for a model run.

10. Run the SNTemp executable, using the SNTemp job and input files created by step 9.

11. The execution of SNTemp in step 10 will produce all of the standard SNTemp output files as described by Theurer and others (1984, p. III-72-III-75). In addition, a PRMS formatted Animation File will be produced (Markstrom and others, 2008, p. 97-99). 
Table 1. Precipitation Runoff Modeling System (PRMS) variables which must be written to the PRMS animation file to be used as input by P2S.

[nsegment, number of stream segments in the stream network; nhru, number of hydrologic response units in the basin; $\mathrm{ft}^{3} / \mathrm{s}$, cubic feet per second; HRU, hydrologic response unit; float, floating point format]

\begin{tabular}{lllll}
\hline \multicolumn{1}{c}{ Variable name } & \multicolumn{1}{c}{ Description } & Dimension & Units & Type \\
\hline seginc_gwflow & lateral groundwater flow to segment & nsegment & $\mathrm{ft}^{3} / \mathrm{s}$ & float \\
seginc_sroff & lateral surface runoff to segment & nsegment & $\mathrm{ft}^{3} / \mathrm{s}$ & float \\
seginc_ssflow & lateral subsurface flow to segment & nsegment & $\mathrm{ft}^{3} / \mathrm{s}$ & float \\
seg_outflow & total streamflow in segment & nsegment & $\mathrm{ft}^{3} / \mathrm{s}$ & float \\
\hline
\end{tabular}




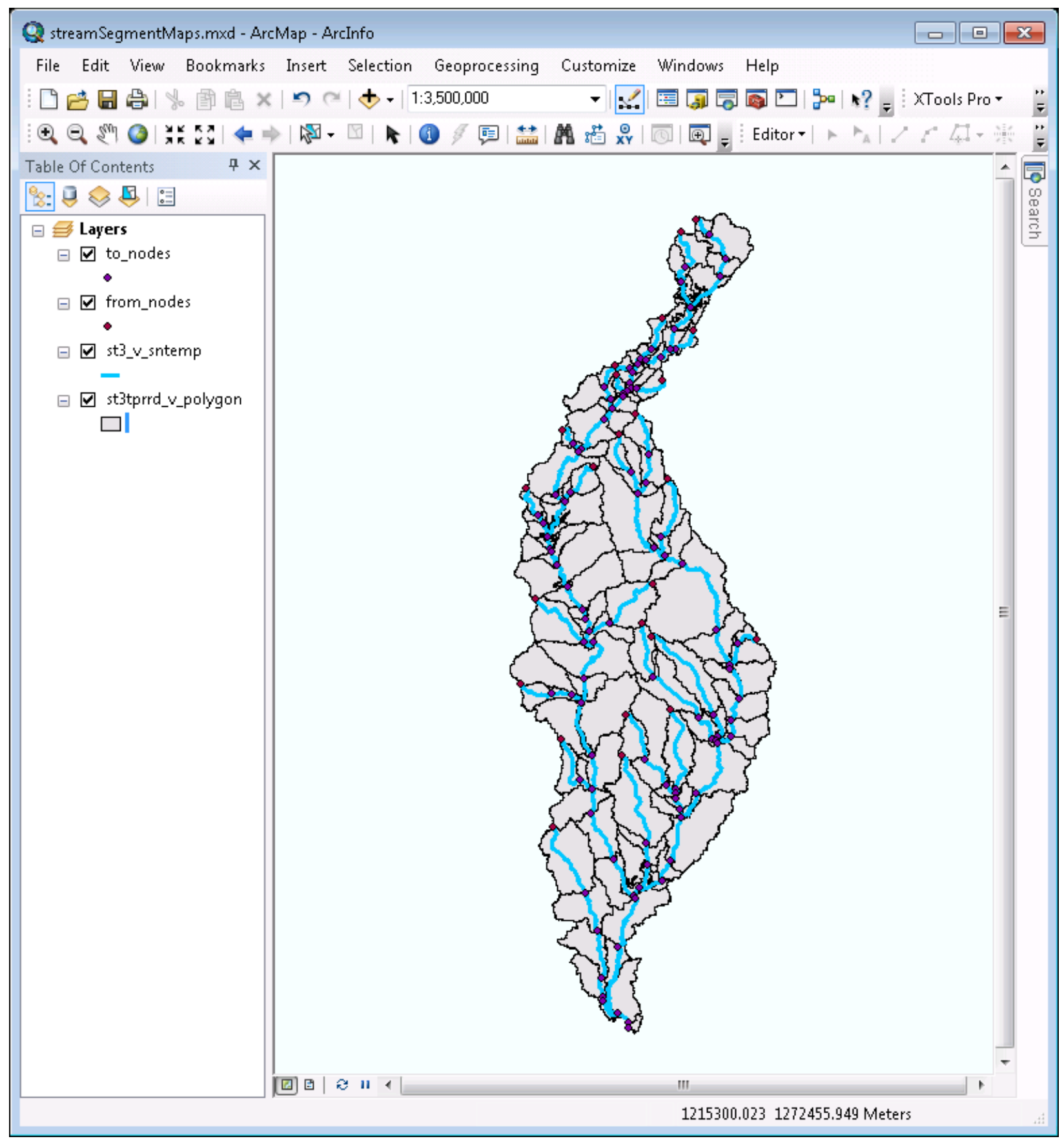

Figure 4. A screen image of an ESRI ArcMap project showing a stream segment network shapefile and the associated attribute table. 
Table 2. Attributes which must be present in the Stream Segement shapefile coverage to describe the topology and physical attributes of the stream segement network to P2S.

[float, floating point format]

\begin{tabular}{|c|c|c|c|}
\hline Attribute name & Description & Units & Type \\
\hline FNODE_ & $\begin{array}{l}\text { Unique identifier of upstream node } \\
\text { (automatically omes from ArcMap) }\end{array}$ & none & integer \\
\hline$T N O D E_{-}$ & $\begin{array}{l}\text { Unique identifier of downstream node } \\
\text { (automatically comes from ArcMap) }\end{array}$ & none & integer \\
\hline GRID_CODE & $\begin{array}{l}\text { Unique identifier of segment, from one } \\
\text { to the total number of segments }\end{array}$ & none & integer \\
\hline LENGTH & Length of segment & meters & float \\
\hline$F_{-} A L T$ & Altitude of upstream node & meters & float \\
\hline$T \_A L T$ & Altitude of downstream node & meters & float \\
\hline$F_{-} L A T$ & Latitude of upstream node & radians & float \\
\hline$T_{-} L A T$ & Latitude of downstream node & radians & float \\
\hline$F \_X$ & $\mathrm{X}$ coordinate of upstream node & meters & float \\
\hline$F_{-} Y$ & Y coordinate of upstream node & meters & float \\
\hline$T \_X$ & $\mathrm{X}$ coordinate of downstream node & meters & float \\
\hline$T_{-} Y$ & Y coordinate of downstream node & meters & float \\
\hline WIDTH & Channel width & meters & float \\
\hline WIDTH_EXP & $\begin{array}{l}\text { Exponent in channel width equation } \\
\text { (usually set to } 0.0 \text { ) }\end{array}$ & none & float \\
\hline MANNING & Manning's roughness coefficient (n) & none & float \\
\hline GRNDTEMP & Average annual ground temperature & degrees Celsius & float \\
\hline THERMGD & Thermal gradient across stream bed & $\begin{array}{l}\text { Joules/square meter/second/ } \\
\text { degrees Celsius }\end{array}$ & float \\
\hline ETOPALT & $\begin{array}{l}\text { East side topological altitude. Angle } \\
\text { from the centerline of the stream } \\
\text { segment. }\end{array}$ & radians & float \\
\hline ECROWN & East side crown height & meters & float \\
\hline EVEGHT & East side vegetation height & meters & float \\
\hline EVEGOFF & East side vegetation offset & meters & float \\
\hline EVDENSUM & East side summer vegetation density & decimal fraction & float \\
\hline EVDENWIN & East side winter vegetation density & decimal fraction & float \\
\hline WTOPALT & $\begin{array}{l}\text { West side topological altitude. Angle } \\
\text { from the centerline of the stream } \\
\text { segment. }\end{array}$ & radians & float \\
\hline WCROWN & West side crown height & meters & float \\
\hline WVEGHT & West side vegetation height & meters & float \\
\hline WVEGOFF & West side vegetation offset & meters & float \\
\hline WVDENSUM & West side summer vegetation density & decimal fraction & float \\
\hline WVDENWIN & West side winter vegetation density & decimal fraction & float \\
\hline
\end{tabular}




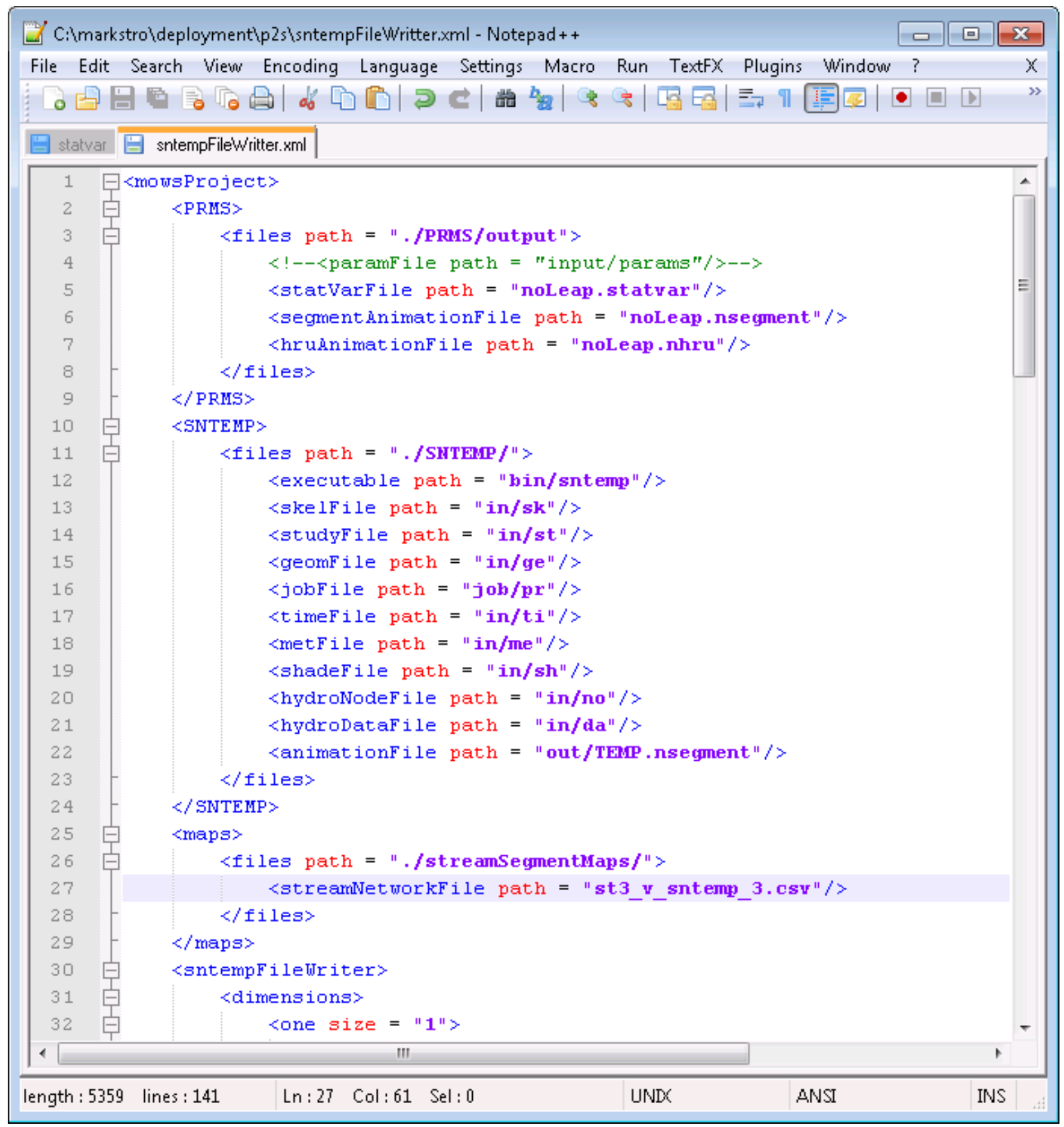

Figure 5. A portion of the Extensible Markup Language (.xml) format file containing Stream Network Temperature Model input values. 
Table 3. Stream Network Temperature Model (SNTemp) input values which must be present in "p2s.xml" input file. These values are described by Theurer and others (1984, p. III-63-III-92).

[nsegment, number of stream segments in the stream network; float, floating point format]

\begin{tabular}{|c|c|c|c|c|}
\hline Variable name & Description & Dimension & Units & Type \\
\hline basinLatitude & latitude of the centroid of the watershed & 1 & radians & float \\
\hline evapFactor & $\begin{array}{l}\text { coefficients for stream evaporation } \\
\text { computations (Theurer and others, 1984, } \\
\text { II-38) }\end{array}$ & 4 & decimal fraction & float \\
\hline bowenRatio & $\begin{array}{l}\text { coefficients for convection computations } \\
\text { (Theurer and others, 1984, p. II-39) }\end{array}$ & 1 & decimal fraction & float \\
\hline airTempConstant & $\begin{array}{l}\text { air temperature calibration factor (Theurer } \\
\text { and others, } 1984, \text { p. II-82) }\end{array}$ & 1 & degrees Celsius & float \\
\hline airTempCoef & $\begin{array}{l}\text { air temperature calibration factor (Theurer } \\
\text { and others, } 1984, \text { p. II-82) }\end{array}$ & 1 & decimal fraction & float \\
\hline windConstant & $\begin{array}{l}\text { wind speed calibration factor (Theurer } \\
\text { and others, 1984, p. II-82) }\end{array}$ & 1 & meters/ second & float \\
\hline windCoef & $\begin{array}{l}\text { wind speed calibration factor (Theurer } \\
\text { and others, 1984, p. II- } 82 \text { ) }\end{array}$ & 1 & decimal fraction & float \\
\hline humidConstant & $\begin{array}{l}\text { relative humidity calibration factor } \\
\text { (Theurer and others, 1984, p. II-82) }\end{array}$ & 1 & decimal fraction & float \\
\hline humidCoef & $\begin{array}{l}\text { relative humidity calibration factor } \\
\text { (Theurer and others, 1984, p. II-82) }\end{array}$ & 1 & decimal fraction & float \\
\hline sunshineConstant & $\begin{array}{l}\text { sunshine calibration factor (Theurer and } \\
\text { others, 1984, p. II-82) }\end{array}$ & 1 & $\begin{array}{l}\text { Joules/ square meter/ } \\
\text { second }\end{array}$ & float \\
\hline sunshineCoef & $\begin{array}{l}\text { sunshine calibration factor (Theurer and } \\
\text { others, 1984, p. II-82) }\end{array}$ & 1 & decimal fraction & float \\
\hline solarConstant & $\begin{array}{l}\text { solar radiation calibration factor (Theurer } \\
\text { and others, } 1984, \text { p. II- } 82 \text { ) }\end{array}$ & 1 & decimal fraction & float \\
\hline solarCoef & $\begin{array}{l}\text { solar radiation calibration factor (Theurer } \\
\text { and others, 1984, p. II-82) }\end{array}$ & 1 & decimal fraction & float \\
\hline windSpeed & $\begin{array}{l}\text { mean daily wind speed, by month, for the } \\
\text { watershed }\end{array}$ & 12 & meters/ second & float \\
\hline relativeHumidity & $\begin{array}{l}\text { mean daily relative humidity, by month, } \\
\text { for the watershed }\end{array}$ & 12 & decimal fraction & float \\
\hline fractionSun & $\begin{array}{l}\text { mean daily solar radiation transmission } \\
\text { fraction, by month, for the watershed }\end{array}$ & 12 & decimal fraction & float \\
\hline dustCoef & $\begin{array}{l}\text { mean daily solar radiation transmission } \\
\text { reduction fraction due to dust, by month, } \\
\text { for the watershed }\end{array}$ & 12 & decimal fraction & float \\
\hline groundReflectivity & $\begin{array}{l}\text { mean daily ground surface albedo, by } \\
\text { month, for the watershed }\end{array}$ & 12 & decimal fraction & float \\
\hline basinLatitude & latitude of the centroid of the watershed & 1 & radians & float \\
\hline evapFactor & $\begin{array}{l}\text { coefficients for stream evaporation } \\
\text { computations (Theurer and others, 1984, } \\
\text { II-38) }\end{array}$ & 4 & decimal fraction & float \\
\hline bowenRatio & $\begin{array}{l}\text { coefficients for convection computations } \\
\text { (Theurer and others, 1984, p. II-39) }\end{array}$ & 1 & decimal fraction & float \\
\hline airTempConstant & $\begin{array}{l}\text { air temperature calibration factor (Theurer } \\
\text { and others, } 1984, \text { p. II-82) }\end{array}$ & 1 & degrees Celsius & float \\
\hline airTempCoef & $\begin{array}{l}\text { air temperature calibration factor (Theurer } \\
\text { and others, 1984, p. II-82) }\end{array}$ & 1 & decimal fraction & float \\
\hline windConstant & $\begin{array}{l}\text { wind speed calibration factor (Theurer } \\
\text { and others, } 1984, \text { p. II-82) }\end{array}$ & 1 & meters/second & float \\
\hline
\end{tabular}




\section{Steps for Making the Stream Segment Shapefile}

These are the steps required to make the stream segment shapefile using ArcMap. This shapefile is required for step 5 above in the "P2S Execution" section of this report.

1. Get the stream network shapefile used for the PRMS model.

2. Open the attribute table and sort on GRID_CODE. This is the stream segment identifier (ID). The goal is to make these go from one to the total number of segments, one (and only one) row for each segment.

3. Move down through the attribute table looking for multiple polylines with the same GRID_CODE. Merge these polylines into one poly line with the appropriate GRID_CODE. Pay attention to FROM_NODE and TO_NODE, as the network topology (which segments are connected together and direction of flow) is important.

4. Click on the Show Directions toggle button in XTools Pro (http://www.xtoolspro.com, accessed March 2012) to see which direction the stream segments are going. If segments are going the wrong direction, click on Editor->Start Editing. Then double click on the segment to select it. Then right click on the mouse and choose Flip from the menu. Click on Editor->Stop Editing.

5. Create two new shapefiles named "from_nodes" and "to_nodes" with XTools Pro. Use Feature Conversions- $>$ Convert Features to Points. Select Points- $>$ End Points- $>$ From and set the Output Storage (shapefile name) to "from_node." Select Points->End Points->To and set the Output Storage to "to_node."

6. Use these shapefiles to determine if the stream segments are connected correctly. Fix them if they are not.

7. Use the from_nodes and to_nodes shapefiles for the rest of the calculations but keep them separate from the original stream segment file.

8. Add the attributes (definitions shown in table 2) to the stream segment shapefile (shapefile used in steps 1-4). These are:

1. LENGTH, use Calculate Geometry, Property is Length and Units is meters.

2. F_ALT, use the Extract Values to Points (Spatial Analyst Tools->Extract Values to Points) with the from_nodes shapefile and a digital elevation model map that covers the spatial extent of the study watershed and make a temporary map. Join this map to the stream_segment shapefile and copy the from_nodes altitudes to the F_ALT attribute with the Field Calculator. Remove the Join.

3. T_ALT, repeat step $b$, but use the to_nodes shapefile.

4. F_LAT, use Data Management Tools->Projections and Transformations->Feature- $>$ Project. The Input Feature Class is the from_nodes shapefile. The Ouput Coordinate System is Select->USGS_Favorites->North American Datum 1983. Add the attribute F_LAT to the new map that was just created by the tool. Right click on the label and select $\bar{C}$ alculate Geometry. Choose Y Coordinate of Point as the Property. Join this map to the stream_segment map and copy the values over as in step $b$.

5. T_LAT, as in step d, but use the to_nodes shapefile.

6. F_X, use the Calculate Geometry- $>$ X Coordinate of Line Start to fill the values.

7. F_Y, use the Calculate Geometry->Y Coordinate of Line Start to fill the values. 
8. T_X, use the Calculate Geometry->X Coordinate of Line End to fill the values.

9. T_Y, use the Calculate Geometry->Y Coordinate of Line End to fill the values.

10. WIDTH, estimate channel width from external data sources.

11. WIDTH_EXP, the default value is 0.0 .

12. MANNING, estimate channel roughness from external data sources.

13. GRNDTEMP, use the average air temperature over the time period of the study.

14. THERMGD, default value is 1.65 .

15. ETOPALT, estimate the east side topological altitude from external data sources.

16. ECROWN, estimate the east side crown height from external data sources.

17. EVEGHT, estimate the east side vegetation height from external data sources.

18. EVEGOFF, estimate the east side vegetation offset from external data sources.

19. EVDENSUM, estimate the east side summer vegetation density from external data sources.

20. EVDENWIN, estimate the east side winter vegetation density from external data sources.

21. WTOPALT, estimate the west side topological altitude from external data sources.

22. WCROWN, estimate the west side crown height from external data sources.

23. WVEGHT, estimate the west side vegetation height from external data sources.

24. WVEGOFF, estimate the west side vegetation offset from external data sources.

25. WVDENSUM, estimate the west side summer vegetation density from external data sources.

26. WVDENWIN, estimate the west side winter vegetation density from external data sources.

\section{Summary}

This report introduces P2S as a software system which couples the daily stream temperature simulation capabilities of the U.S. Geological Survey Stream Network Temperature model with the watershed hydrology simulation capabilities of the U.S. Geological Survey Precipitation-Runoff Modeling System. Instructions are provided for system installation and preparation and manipulation of the various inputs which are required. Following the guidelines presented here will result in a successful stream temperature model application.

\section{References Cited}

Bartholow, J.M., 2000, The stream segment and stream network temperature models: a self-study course: U.S. Geological Survey Open-File Report 99-112, 270 p.

Brown, G.W., 1969, Predicting temperatures of small streams: Water Resources Research, v. 5, no. 1, p. $68-75$.

Flint, L.E., and Flint, A.L., 2008, A basin-scale approach to estimating stream temperatures of tributaries to the Lower Klamath River, California: Journal of Environmental Quality, no. 37, p. $57-$ 68.

Gaffield, S.J., Potter, K.W., and Wang, Lizhu, 2005, Prediction the summer temperature of small streams in southwestern Wisconsin: Journal of the American Water Resources Association, v. 41, no. 1, p. 25-36. 
Hay, L.E., Markstrom, S.L., and Ward-Garrison, C.D., 2011, Watershed-scale response to climate change through the twenty-first century for selected basins across the United States: Earth Interactions, v. 15, $37 \mathrm{p}$.

Leavesley, G.H., Lichty, R.W., Troutman, B.M., and Saindon, L.G., 1983, Precipitation-runoff modeling system-User's manual: U.S. Geological Survey Water-Resources Investigations Report 834238, $207 \mathrm{p}$.

Leavesley, G.H., Markstrom, S.L., Viger, R.J., and Hay, L.E., 2005, USGS Modular Modeling System (MMS) - Precipitation-Runoff Modeling System (PRMS) MMS-PRMS, in Singh, V.P., and Frevert, D.K., eds., Watershed models: Boca Raton, Fla., CRC Press, p. 159-177.

Leavesley, G.H., and Stannard, L.G., 1995, The precipitation-runoff modeling system-PRMS, in Singh, V.P., ed., Computer models of watershed hydrology: Highlands Ranch, Colo., Water Resources Publications, p. 281-310.

Markstrom, S.L., Hay, L.E., Ward-Garrison, C.D., Risley, J.C., Battaglin, W.A., Bjerklie, D.M., Chase, K.J., Christiansen, D.E. Dudley, R.W., Hunt, R.J., Koczot, K.M., Mastin, M.C., Regan, R.S., Viger, R.J., Vining, K.C., and Walker, J.F., 2012, Integrated watershed-scale response to climate change for selected basins across the United States: U.S. Geological Survey Scientific Investigations Report 2011-5077, $153 \mathrm{p}$.

Markstrom, S.L., and Koczot, K.M., 2008, User's manual for the object user interface (OUI)—An environmental resource modeling framework: U.S. Geological Survey Open-File Report 2008-1120, $39 \mathrm{p}$.

Markstrom, S.L., Niswonger, R.G., Regan, R.S., Prudic, D.E., and Barlow, P.M., 2008, GSFLOWCoupled ground-water and surface-water flow model based on the integration of the PrecipitationRunoff Modeling System (PRMS) and the Modular Ground-Water Flow Model (MODFLOW-2005): U.S. Geological Survey Techniques and Methods 6-D1, 240 p.

Perry, R.W., Risley, J.C., Brewer, S.J., Jones, E.C., and Rondorf, D.W., 2011, Simulating daily water temperatures of the Klamath River under dam removal and climate change scenarios: U.S. Geological Survey Open-File Report 2011-1243, 78 p.

Sinokrot, B.A., and Stefan, H.G., 1993, Stream temperature dynamics-Measurements and modeling: Water Resources Research, v. 29, no. 7, p. 2299-2312.

Theurer, F.D., Voos, K.A., and Miller, W.J., 1984, Instream water temperature model: U.S. Fish and Wildlife Service Instream Flow Information Paper 16, FWS/OBS-85/15, 316 p. 


\section{Appendix 1. Documentation of the Muskingum Module}

\section{Introduction}

This appendix describes the inputs and outputs, equations, computations, references, assumptions, and limitations of the new PRMS modules that were developed for this study. Each described module is encoded as a Fortran 90 source code file.

\section{Styles and Formats}

The following font styles and formats are used in this Appendix:

- Module variables are identified 12-point, italic, Times font.

- Module parameters and dimensions are identified 12-point, bold, Times font.

- Constants are identified using upper case 12-point, bold, Times font.

- Module names are identified in 12-point, Courier font.

\section{Muskingum Routing Module: muskingum}

The muskingum module was originally developed for the Precipitation Runoff Modeling System (PRMS) by Mastin and Vaccaro (2002) and developed further by Markstrom and others (2008). This module has been modified from past versions to make it more stable for stream network routing in watersheds with stream segments with varying travel times. Although this module runs on the same daily time step as the rest of the modules in PRMS, it has an internal structure which allows for a different computational time step for each segment in the stream network, ensuring that the simulation produces stable values. Flow values computed at these finer time steps are aggregated by the Muskingum module to provide consistent daily time step values, regardless of the segment length. This module should be used for streamflow routing when PRMS is coupled to SNTemp with P2S. The input parameters used by the muskingum module to compute flow are defined in table A1-1. The computed variables are defined in table A1-2. All equation symbols used in this section are defined in these two tables. 
Table A1-1.-Input parameters to Streamflow Module: muskingum.

[HRU, hydrologic response unit; nhru, number of HRUs; nsegment, number of stream segments]

\begin{tabular}{|c|c|c|c|c|c|c|}
\hline $\begin{array}{l}\text { Parameter } \\
\text { name }\end{array}$ & Description & $\begin{array}{l}\text { Dimension } \\
\text { variable }\end{array}$ & Units & Type & Range & $\begin{array}{l}\text { Default } \\
\text { value }\end{array}$ \\
\hline hru_segment & $\begin{array}{l}\text { Segment index to which an HRU contributes } \\
\text { lateral flows (surface runoff, interflow, and } \\
\text { groundwater discharge) }\end{array}$ & nhru & none & integer & $\begin{array}{c}0 \text { to } \\
\text { nsegment }\end{array}$ & 0 \\
\hline k_coef & $\begin{array}{l}\text { Travel time from one segment to the next } \\
\text { downstream segment, called the Muskingum } \\
\text { storage coefficient; enter } 0.0 \text { for reservoirs, } \\
\text { diversions, and segment(s) flowing out of the } \\
\text { basin }\end{array}$ & nsegment & hours & real & $\begin{array}{l}0.0 \text { to } \\
240.0\end{array}$ & 0.0 \\
\hline obsin_segment & $\begin{array}{l}\text { Index of measured streamflow station that replaces } \\
\text { inflow to a segment }\end{array}$ & nsegment & none & integer & $\begin{array}{c}0 \text { to } \\
\text { nsegment }\end{array}$ & 0 \\
\hline to_segment & $\begin{array}{l}\text { Index of downstream segment to which the } \\
\text { segment streamflow flows, for segments that do } \\
\text { not flow to another segment enter } 0\end{array}$ & nsegment & none & integer & $\begin{array}{c}0 \text { to } \\
\text { nsegment }\end{array}$ & 0 \\
\hline x_coef & $\begin{array}{l}\text { The amount of attenuation of the hydrograph, } \\
\text { called the Muskingum routing weighting factor; } \\
\text { enter } 0.0 \text { for reservoirs, diversions, and segment(s) } \\
\text { flowing out of the basin }\end{array}$ & nsegment & hours & real & 0.0 to 0.5 & 0.2 \\
\hline
\end{tabular}




\section{Table A1-2._-Variables used in Streamflow Module: muskingum.}

[HRU, hydrologic response unit; GWR, groundwater reservoir; nhru, number of HRUs; one, a constant; ngw, number of groundwater reservoirs; nobs, number of streamflow-gaging stations; nssr, number of subsurface reservoirs (must be specified equal to nhru); nsegment, number of stream segments; $\mathrm{ft}^{3} / \mathrm{s}$, cubic feet per second]

\begin{tabular}{|c|c|c|c|c|}
\hline Variable name & Description & Dimension & Units & Type \\
\hline \multicolumn{5}{|c|}{ Input variables } \\
\hline basin_gwflow & $\begin{array}{l}\text { Basin area-weighted average of groundwater flow to the } \\
\text { stream network }\end{array}$ & one & inches & double \\
\hline basin_sroff & $\begin{array}{l}\text { Basin area-weighted average of surface runoff to the stream } \\
\text { network }\end{array}$ & one & inches & double \\
\hline basin_ssflow & $\begin{array}{l}\text { Basin area-weighted average interflow from gravity and } \\
\text { preferential-flow reservoirs to the stream network }\end{array}$ & one & inches & double \\
\hline basin_stflow & $\begin{array}{l}\text { Basin area-weighted average streamflow leaving through } \\
\text { the stream network }\end{array}$ & one & inches & double \\
\hline gwres flow & $\begin{array}{l}\text { Groundwater discharge from each GWR to the stream } \\
\text { network }\end{array}$ & ngw & inches & real \\
\hline sroff & Surface runoff to the stream network for each HRU & nhru & inches & real \\
\hline ssres_flow & $\begin{array}{l}\text { Interflow from gravity and preferential-flow reservoir to the } \\
\text { stream network for each HRU }\end{array}$ & nssr & inches & real \\
\hline streamflow_cfs & Streamflow at each measurement station & nobs & $\mathrm{ft}^{3} / \mathrm{s}$ & real \\
\hline swrad & Shortwave radiation distributed to each HRU & nhru & langleys & real \\
\hline \multicolumn{5}{|c|}{ Output variables } \\
\hline seg_lateral_inflow & Lateral inflow entering a segment & nsegment & $\mathrm{ft}^{3} / \mathrm{s}$ & real \\
\hline seg_upstream_inflow & Sum of inflow from upstream segments & nsegment & $\mathrm{ft}^{3} / \mathrm{s}$ & real \\
\hline seg_loss & Outflow to outside the stream network from a segment & nsegment & $\mathrm{ft}^{3} / \mathrm{s}$ & real \\
\hline seg_gain & Inflow from outside the stream network to a segment & nsegment & $\mathrm{ft}^{3} / \mathrm{s}$ & real \\
\hline seg_inflow & Streamflow entering a segment & nsegment & $\mathrm{ft}^{3} / \mathrm{s}$ & real \\
\hline seginc_gwflow & $\begin{array}{l}\text { Area-weighted average groundwater discharge for each } \\
\text { segment from HRUs contributing flow to the segment }\end{array}$ & nsegment & $\mathrm{ft}^{3} / \mathrm{s}$ & real \\
\hline seginc_swrad & $\begin{array}{l}\text { Area-weighted average solar radiation for each segment } \\
\text { from HRUs contributing flow to the segment }\end{array}$ & nsegment & langleys & real \\
\hline seg_outflow & Streamflow leaving a segment & nsegment & $\mathrm{ft}^{3} / \mathrm{s}$ & real \\
\hline
\end{tabular}


The Muskingum routing equation assumes a linear relation between storage and the characteristics of the inflow ( $\operatorname{seg} \_$inflow $\left.w_{\text {segment }}^{t}\right)$ and outflow $\left(\operatorname{seg} \_\right.$outflow $\left.w_{\text {segment }}^{t}\right)$. Storage

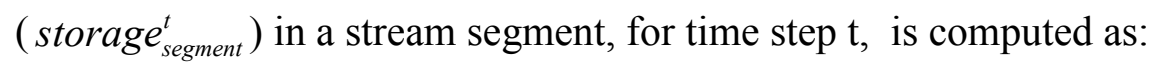

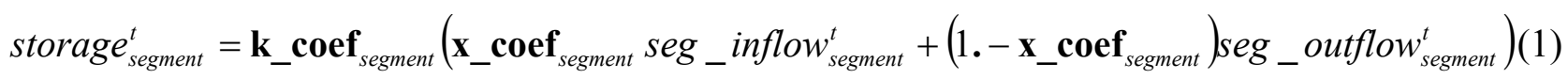

Assuming that the average flow during a routing period is equal to the average flow at the start and end times of the routing period, the continuity equation can be expressed as:

$$
\begin{aligned}
& \Delta \text { storage }_{\text {segment }}^{t}=\text { storage }_{\text {segment }}^{t}-\text { storage }_{\text {segment }}^{t-1}
\end{aligned}
$$

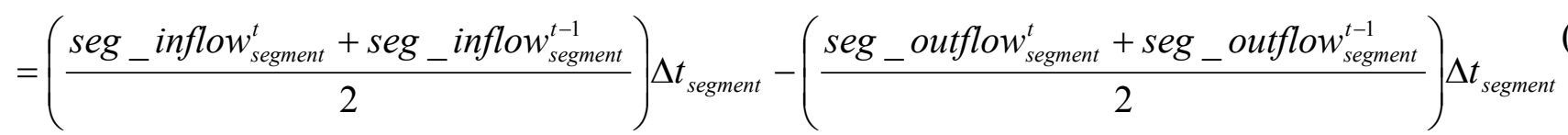

Substituting equation 1 into equation 2 and solving for the stream segment outflow, for the current time step, results in:

$$
\begin{aligned}
& \text { seg_outflow } w_{\text {segment }}^{t}= \\
& \qquad 0_{\text {segment }}\left(\operatorname{seg} \text { inflow }_{\text {segment }}^{t}\right)+\mathrm{c} 1_{\text {segment }}\left(\operatorname{seg} \_ \text {inflow } w_{\text {segment }}^{t-1}\right)+\mathrm{c} 2_{\text {segment }}\left(\text { seg_outflow } w_{\text {segment }}^{t-1}\right)
\end{aligned}
$$

where

$$
\begin{aligned}
& -\left(\mathbf{k} \_ \text {coef }_{\text {segment }} \mathbf{x} \_ \text {coef }_{\text {segment }}\right)+\frac{\Delta t_{\text {segment }}}{2}
\end{aligned}
$$

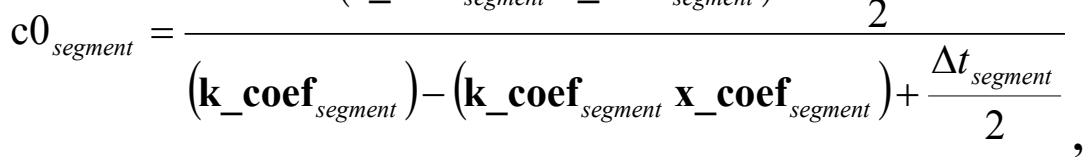

$$
\begin{aligned}
& \mathrm{c} 1_{\text {segment }}=\frac{\left(\mathbf{k} \_\mathbf{c o e f}_{\text {segment }} \mathbf{x} \_\mathbf{c o e f}_{\text {segment }}\right)+\frac{\Delta t_{\text {segment }}}{2}}{\left(\mathbf{k} \text { coef }_{\text {segment }}\right)-\left(\mathbf{k} \_ \text {coef }_{\text {segment }} \mathbf{x} \mathbf{c o e f}_{\text {segment }}\right)+\frac{\Delta t_{\text {segment }}}{2}}, \text { and }
\end{aligned}
$$

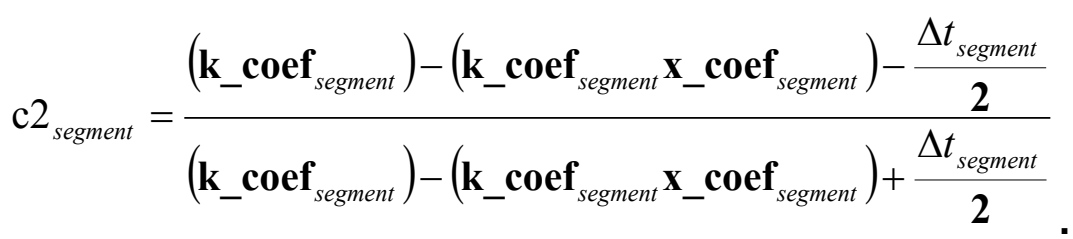

$\Delta t_{\text {segment }}$ in equations 2 and 3 is the solution time step, calculated internally by the muskingum module for each stream segment according to:

$$
\Delta t_{\text {segment }}=\left\lfloor\frac{24}{\left.\left[\frac{24}{\mid \mathbf{k}_{\text {coef }}^{\text {segment }}}\right]\right\rceil}\right\rfloor
$$


which is the travel time (in hours), rounded down to an even divisor of 24 hours (for example 24, 12, 6 , $4,3,2$, and 1). PRMS is restricted to daily time steps, so $\Delta t_{\text {segment }}$ can never be more than one day in length. This means that the travel time of any segment in the stream network ( $\mathbf{k}_{-}$coef $_{\text {segment }}$ ) must be less than one day. An implication of equation 4 is that the routed streamflow in each segment is computed using different solution time steps. Consequently, streamflow must be aggregated when flowing from segments with shorter $\Delta t_{\text {segment }}$ to segments with longer $\Delta t_{\text {segment }}$. Likewise, streamflow must be disaggregated when flowing from segments with longer $\Delta t_{\text {segment }}$ to shorter $\Delta t_{\text {segment }}$. In either case, flow from upstream segments is averaged and summed to the appropriate value of $\Delta t_{\text {segment }}$.

\section{References Cited}

Markstrom, S.L., Niswonger, R.G., Regan, R.S., Prudic, D.E., and Barlow, P.M., 2008, GSFLOWCoupled ground-water and surface-water flow model based on the integration of the PrecipitationRunoff Modeling System (PRMS) and the Modular Ground-Water Flow Model (MODFLOW-2005): U.S. Geological Survey Techniques and Methods 6-D1, 240 p.

Mastin, M.C., and Vaccaro, J.J., 2002, Documentation of Precipitation Runoff Modeling System modules for the Modular Modeling System modified for the Watershed and River Systems Management Program: U.S. Geological Survey Open-File Report 2002-362, 5 p. 